\title{
The Aerophytic Diatom Assemblages Developed on Mosses Covering the Bark of Populus alba L.
}

\author{
Mateusz Rybak' ${ }^{1}$, Teresa Noga ${ }^{2}$, Robert Zubel ${ }^{3}$ \\ 1 Department of Agroecology, Faculty of Biology and Agriculture, University of Rzeszów, Ćwiklińskiej 1A, \\ 35-601 Rzeszów, Poland \\ 2 Department of Soil Studies, Environmental Chemistry and Hydrology, Faculty of Biology and Agriculture, \\ University of Rzeszów, Zelwerowicza 8B, 35-601 Rzeszów, Poland \\ 3 Department of Botany and Mycology, Maria Curie-Skłodowska University, ul. Akademicka 19, 20-033 Lublin, \\ Poland \\ * Corresponding author's e-mail: teresa.noga@interia.pl
}

\begin{abstract}
The study was conducted in an old, historical park, in the northern part of Stalowa Wola city (south-eastern Poland). The aim of the study was to investigate the diversity of moss-inhabiting diatoms of the white poplar (Populus alba L.) bark. During the study, a total of 47 diatom taxa were found, three out of which were considered as dominant. Three other species are mentioned in the Red List of the Algae in Poland: Achnanthes coarctata (Brébisson) Grunow, Luticola acidoclinata Lange-Bertalot and Stauroneis thermicola (Petersen) Lund. For three species: Luticola sparsipunctata Levkov, Metzeltin \& Pavlov, L. vanheurckii Van de Vijver \& Levkov and Hantzschia subrupestris Lange-Bertalot, this is the first report from Poland.
\end{abstract}

Keywords: diatoms, tree bark, mosses, diversity, ecology

\section{INTRODUCTION}

Many algae species can survive and develop outside of the aquatic habitats - on a trees bark, on leaves, on wet walls and rocks, or on wet to semi-wet soils. They occur in continuously or only periodically wet habitats, using water in the form of atmospheric precipitation, dew, fog and moisture contained in the air. The aerophytic algae develop most abundantly in a warm and humid climate (Podbielkowski 1996).

The arboreal algae find a specific and favourable microclimate on the bark of trees that provide shade, nutrients and shelter against wind. In Europe, the trees bark is usually covered with green algae (mostly Pleurococcus vulgaris Meneghini, Protococcus viridis C. Agardh and Chlorella vulgaris Beyerinck), rarely with blue-green algae and diatoms (the latter presumably due to the absence of silica in the environment). The arboreal algae have wide ecological amplitude. They are known for their nitrogenous compounds toler- ance, so they can live even on the trees growing in cities (Kawecka, Eloranta 1994).

The mosses growing on the tree bark use it only as a substrate, while all nutrients are taken by mosses from an atmospheric precipitation or from the air humidity. The diversity of epiphytic bryophytes is affected by both the chemical $(\mathrm{pH})$ and physical (including structure of surface and water absorption capacity) properties of the bark. In numerous ecosystems, bryophytes form an expansive cover that accumulates water and organic particles, providing a favourable environment for many organisms, from bacteria, algae and fungi to small animals (Lindo, Gonzales 2010, Plášek 2013, Glime 2017).

The studies on the moss-inhabiting diatoms (bryophytic diatoms) are most often related to peatland areas, mainly including the mosses from the genus Sphagnum spp. (Nováková, Poulíčková 2004, Poulíčková et al. 2004). The diatoms developing among the typical terrestrial bryophytes are very rarely studied, mainly on the mosses growing 
on rocks (Round 1957) and on terrestrial mosses occurring in the polar regions (e.g. Hickman, Vitt 1973, Van de Vijver, Beyens 1997, Gremmen et al. 2007). Until now, the algological studies of tree barks have focused mainly on the green and bluegreen algae in tropical zones (Foerester 1971, Mrozińska 1990, Thompson, Wujek 1997, Salleh, Milow 1999, Neustupa 2003, 2005, Neustupa, Škaloud 2008, 2010, Kharkongor, Ramanujam 2014, Štifterová, Neustupa 2015), while diatoms were noted rarely, usually mentioned only in the lists of species (Lakatos et al. 2004, Geissler et al. 2006, Neustupa, Škaloud 2010, Kharkongor, Ramanujam 2014, Štifterová, Neustupa 2015, Qin et al. 2016). In Poland, no studies on the diatom assemblages developing among mosses on the tree barks have been conducted so far.

The aim of the study was to investigate the diversity of diatom assemblages among the mosses growing on the bark of white poplar (Populus alba L.) in relation to chemical parameters $(\mathrm{pH}$, conductivity, anions and cations) measured in the filtrates obtained from the tree bark.

\section{METHODS}

The conducted research concerns the mosses growing on white poplar tree trunk (Populus alba) in an old park, in the northern part of the Stalowa Wola city. The tree from which the research material was taken $\left(50^{\circ} 36^{\prime} 01.1^{\prime \prime} \mathrm{N} 22^{\circ} 01^{\prime} 53.3^{\prime \prime} \mathrm{E}\right)$ grew in an exposed place (about $30 \mathrm{~m}$ from the nearest tree), which resulted in the trunk being directly illuminated. Mosses covered the base of the trunk in almost $100 \%$, while on the trunk up to the height of $150 \mathrm{~cm}$ above the ground level, they formed small clumps (less than $5 \%$ of the bark surface).

The samples were collected in March 2016 and in March, June and August 2017. Small pieces of bark (approx. $8 \times 8 \mathrm{~cm}$ ) covered by mosses were collected from two heights: $20 \mathrm{~cm}$ and 150 $\mathrm{cm}$ above the ground level. The collected material was placed in paper envelopes. In August 2017, the material was collected only at the base of the trunk, because at the height of $150 \mathrm{~cm}$, mosses were absent. During the each sampling, a piece of bark from height of $150 \mathrm{~cm}$ was collected for chemical analyses.

The filtrates for chemical analyses were prepared according to Schmidt et al. (2001). The filtrates were obtained by soaking pieces of bark in deionized water (in weight ratio 1:10) for 24 hours. For the preparation of filtrates, the intact pieces of bark were used to obtain a solution similar to that forming on the surface of the bark that is a source of water and nutrients for epiphytic organisms.

The $\mathrm{pH}$ and electrolytic conductivity were measured using a MARTINI pH56 pH meter and MARTINI EC59 conductivity meter. The ions content was determined using a Thermo scientific DIONEX ICS-5000+DC device in the Departmental Laboratory of Analysis of Environmental Health and Materials of Agricultural Origin at the University of Rzeszów.

In order to obtain cleaned diatom material, a modified Qin et al. (2016) method was used:

1 . For the purpose of separating mosses and diatoms from the bark surface, a part of the collected material was placed in beakers and 50 $\mathrm{ml}$ of $30 \%$ hydrogen peroxide $\left(\mathrm{H}_{2} \mathrm{O}_{2}\right)$ was added, and left at room temperature for 48 hours.

2. In the next step, the bark fragments were rinsed with deionized water, and the formed solution was collected into the same beaker, in which the bark was digested.

3. In order to obtain clean diatom valves, the solution was centrifuged to remove the excess of hydrogen peroxide and again digested in the mixture of sulfuric acid and potassium dichromate, until organic matter was completely dissolved.

4. In the last step the chromic mixture was removed by centrifugation with distilled water (at $2500 \mathrm{rpm}$ ).

For LM (light microscope) slides, pure diatom valves were mounted in Pleurax resin (refractive index 1.75). Diatoms were identified under a Carl Zeiss Axio Imager.A2 light microscope (LM) with a Zeiss AxioCam ICc 5 camera at $1000 \times$ magnification. For Scanning Electron Microscope (SEM), the observations samples were coated at Turbo-Pumped Sputter Coater Quorum Q 150OT ES with a $20 \mathrm{~nm}$ layer of gold and observed under a Hitachi SU 8010 microscope.

The diatoms identification was conducted in accordance with the following references: Krammer and Lange-Bertalot (1986, 1988, 1991a,b), Krammer (2000), Lange-Bertalot et al. (2003), Hofmann et al. (2011) and Levkov et al. (2013). The nomenclature of mosses is according to Ochyra et al. (2003). The habitat and substrate preferences of mosses were determined according to Dierßen (2001), Smith (2004) and Ellenberg, Leuschner (2010). 
The species composition of the samples was determined by counting specimens on randomly selected fields of view under light microscope according to a modified method described by Lakatos et al. (2004). There were about 300 valves. In the samples with low number of valves on slide, all specimens were counted. The species with a share more than 50 valves were defined as dominant.

The categories of endangered for diatom taxa were distinguished using the Red List of the Algae in Poland (Siemińska et al. 2006).

The statistical analyses with graphical interpretation were performed using the Canoco software (version 5.03). In order to analyse the differentiation of individual samples collected at different heights above ground level and in different seasons, the Principal Component Analysis (PCA) was used (Ter Braak, Šmilauer 2012).

\section{RESULTS}

The chemical analysis of filtrates obtained from soaking the bark showed that the solutions had a slightly acidic to neutral $\mathrm{pH}$ (5.3-6.9), while the conductivity values ranged from 43 to $427 \mu \mathrm{S} \mathrm{cm}^{-1}$. The values of ions were significantly higher in the early spring periods compared to the summer season, when the concentration of nutrients decreased even below the limit of quantification (Table 1).

The examined tree was abundantly covered with mosses at the trunk base, while at a height of $150 \mathrm{~cm}$, the mosses were less numerous. The base of the trunk was overgrown by typical terrestrial species: Amblystegium serpens Schimp, Brachythecium salebrosum (Web. Mohr) Schimp., Herzogiella seligeri (Brid.) Z. Iwats., Rosulabryum capillare (Hedw.) and epiphytic: Hypnum cupres- siforme Hedw. and Platygyrium repens (Brid.) Schimp., J.R. Spence. The mosses formed a uniform, thick layer of about $5 \mathrm{~cm}$, completely surrounding the base of the trunk. At the height of $150 \mathrm{~cm}$, there were only single, small clumps of two species Platygyrium repens (Brid.) Schimp. and Orthotrichum speciosum Nees.

During the research carried out in 2016-2017, 47 diatom taxa from 23 genera were observed (Table 2). The most numerous genera were Luticola (9 taxa), followed by Hantzschia (4 taxa). The selected diatom taxa are presented in Figures 1 and 2.

Diatoms were numerous only at the base of the trunk. At the height of $150 \mathrm{~cm}$ above the ground level, only single valves were observed (Table 3). The PCA analysis also split the samples collected at different heights above the ground into two groups. The samples taken from a height of $20 \mathrm{~cm}$ were more varied, compared to those collected from a height of $150 \mathrm{~cm}$, which formed a more compact group (Fig. 3).

Among all the observed diatoms, the dominant ones were: Hantzschia amphioxys, Luticola acidoclinata and Pinnularia borealis. In early spring (both in 2016 and 2017), only one species prevailed in the diatom assemblage - Luticola acidoclinata in 2016 and Hantzschia amphioxys in 2017. In the summer (both in June and August), all three species dominated the diatom flora (Table 3 ).

In the studied assemblages, three diatom species from Red List of the Algae in Poland were recorded (Siemińska et al. 2006). All of them are classified in the R category (rare): Luticola acidoclinata (which is also the dominant species), Achnanthes coarctata and Stauroneis thermicola (both observed as single specimens). In addition, three species have not been reported

Table 1. Values of chemical parameters measured in filtrates obtained from poplar bark in years 2016-2017

\begin{tabular}{|l|c|c|c|c|}
\hline \multicolumn{1}{|c|}{ Date } & 03.2016 & 03.2017 & 06.2017 & 08.2017 \\
\hline $\mathrm{pH}$ & 6.8 & 6.9 & 5.8 & 5.3 \\
\hline Conductivity $\left[\mu \mathrm{S} \mathrm{cm}^{-1}\right]$ & 397 & 427 & 145 & 43 \\
\hline $\mathrm{Cl}^{-}\left[\mathrm{mg} \mathrm{l}^{-1}\right]$ & 12.55 & 14.43 & 1.19 & 0.33 \\
\hline $\mathrm{NO}_{2}^{-}\left[\mathrm{mg} \mathrm{l}^{-1}\right]$ & 1.14 & 2.91 & $<0.001$ & $<0.001$ \\
\hline $\mathrm{NO}_{3}{ }^{-}\left[\mathrm{mg} \mathrm{l}^{-1}\right]$ & 3.63 & 1.37 & $<0.001$ & $<0.001$ \\
\hline $\mathrm{PO}_{4}{ }^{-2}\left[\mathrm{mg} \mathrm{l}^{-1}\right]$ & 3.93 & 3.29 & $<0.001$ & $<0.001$ \\
\hline $\mathrm{SO}_{4}{ }^{2-}\left[\mathrm{mg} \mathrm{l}^{-1}\right]$ & 23.45 & 42.06 & 13.35 & 0.18 \\
\hline $\mathrm{Na}^{+}\left[\mathrm{mg} \mathrm{l}^{-1}\right]$ & 8.80 & 8.44 & 0.40 & 0.21 \\
\hline $\mathrm{NH}_{4}{ }^{+}\left[\mathrm{mg} \mathrm{l}^{-1}\right]$ & 0.43 & 2.23 & 1.10 & 0.08 \\
\hline $\mathrm{K}^{+}\left[\mathrm{mg} \mathrm{l}^{-1}\right]$ & 25.03 & 61.69 & 35.22 & 10.88 \\
\hline $\mathrm{Mg}^{2+}\left[\mathrm{mg} \mathrm{l}^{-1}\right]$ & 23.24 & 20.34 & 1.73 & 0.64 \\
\hline $\mathrm{Ca}^{2+}\left[\mathrm{mg} \mathrm{l}^{-1}\right]$ & 23.14 & 20.04 & 4.94 & 1.91 \\
\hline
\end{tabular}


Table 2. List of diatom taxa found in epiphytic mosses overgrowing the bark of white poplar, at different highs above soil level in years: 2016-2017

\begin{tabular}{|c|c|c|c|c|}
\hline Date & 03.2016 & 03.2017 & 06.2017 & 08.2017 \\
\hline Achnanthes coarctata (Brébisson) Grunow & & & $+\circ$ & \\
\hline Aulacoseira distans (Ehrenberg) Simonsen & + & & & \\
\hline Aulacoseira granulata (Ehrenberg) Simonsen & + & ० & + & \\
\hline Aulacoseira muzzanensis (Meister) Krammer & & & o & + \\
\hline Cocconeis placentula var. lineata (Ehrenberg) Van Heurck & + & & & \\
\hline Cocconeis pseudolineata (Geitler) Lange-Bertalot & $\circ$ & & & \\
\hline Cyclostephanos dubius (Hustedt) Round & & + & + & + \\
\hline Epithemia adnata (Kützing) Brébisson & + & & & \\
\hline Eunotia bilunaris (Ehrenberg) Schaarschmidt & + & + & & \\
\hline Fallacia insociabilis (Krasske) D.G. Mann & & + & & \\
\hline Frustulia saxonica Rabenhorst & + & & & \\
\hline Halamphora montana (Krasske) Levkov & $+\circ$ & & & + \\
\hline Hantzschia abundans Lange-Bertalot & + & $+\circ$ & + & + \\
\hline Hantzschia amphioxys (Ehrenberg) Grunow & $+\circ$ & $+\circ$ & $+\circ$ & + \\
\hline Hantzschia calcifuga Reichardt \& Lange-Bertalot & + & + & + & + \\
\hline Hantzschia subrupestris Lange-Bertalot & $+\circ$ & & & \\
\hline Humidophila contenta (Grunow) Lowe, et al. & + & + & $+\circ$ & + \\
\hline Humidophila gallica (W. Smith) Lowe, et al. & + & & & \\
\hline Luticola acidoclinata Lange-Bertalot & + & + & $+\circ$ & + \\
\hline Luticola sparsipunctata Levkov, Metzeltin \& A. Pavlov & + & + & $+\circ$ & + \\
\hline Luticola vanheurckii Van de Vijver \& Levkov & & $\circ$ & & \\
\hline Luticola ventricosa (Kützing) D.G. Mann, Morphotyp I & & + & & \\
\hline Luticola ventricosa (Kützing) D.G. Mann, Morphotyp II & + & $+\circ$ & & + \\
\hline Luticola cf. nivalis (Ehrenberg) D.G. Mann & + & $+\circ$ & & \\
\hline Luticola sp. 1 & + & + & & + \\
\hline Luticola sp. 2 & $+\circ$ & $+\circ$ & + & + \\
\hline Luticola sp. 3 & + & + & + & + \\
\hline Mayamaea atomus (Kützing) Lange-Bertalot & + & & + & + \\
\hline Mayamaea excelsa (Krasske) Lange-Bertalot & & & + & \\
\hline Mayamaea permitis (Hustedt) K. Bruder \& Medlin & & & + & \\
\hline Meridion circulare (Greville) C. Agardh & & $\circ$ & & \\
\hline Muelleria gibbula (Cleve) Spaulding \& Stoermer & & & ० & \\
\hline Navicula wiesneri Lange-Bertalot & + & $\circ$ & ○ & \\
\hline Nitzschia pusilla Grunow & & & + & + \\
\hline Nitzschia solgensis Cleve-Euler & & & $\circ$ & \\
\hline Orthoseira dendroteres (Ehrenberg) Genkal \& Kulikovskiy & + & & $+\circ$ & + \\
\hline Pantocsekiella sp. & + & ० & ० & \\
\hline Pinnularia borealis Ehrenberg & $+\circ$ & $+\circ$ & $+\circ$ & + \\
\hline Pinnularia issealana Krammer & $\circ$ & & & \\
\hline Pinnularia obscura Krasske & + & $+\circ$ & + & + \\
\hline Sellaphora atomoides (Grunow) Wetzel \& Van de Vijver & + & + & & + \\
\hline Sellaphora saugerresii (Desmazières) Wetzel \& D.G. Mann & & + & & \\
\hline Stauroneis borrichii (Petersen) Lund & & & & + \\
\hline Stauroneis lundii Hustedt & & & & + \\
\hline Stauroneis thermicola (Petersen) Lund & & + & & + \\
\hline Surirella minuta Brébisson & + & & & + \\
\hline Surirella terricola Lange-Bertalot \& Alles & +0 & & & \\
\hline
\end{tabular}

$+\quad 20 \mathrm{~cm}$ above soil level

○ $150 \mathrm{~cm}$ above soil level 


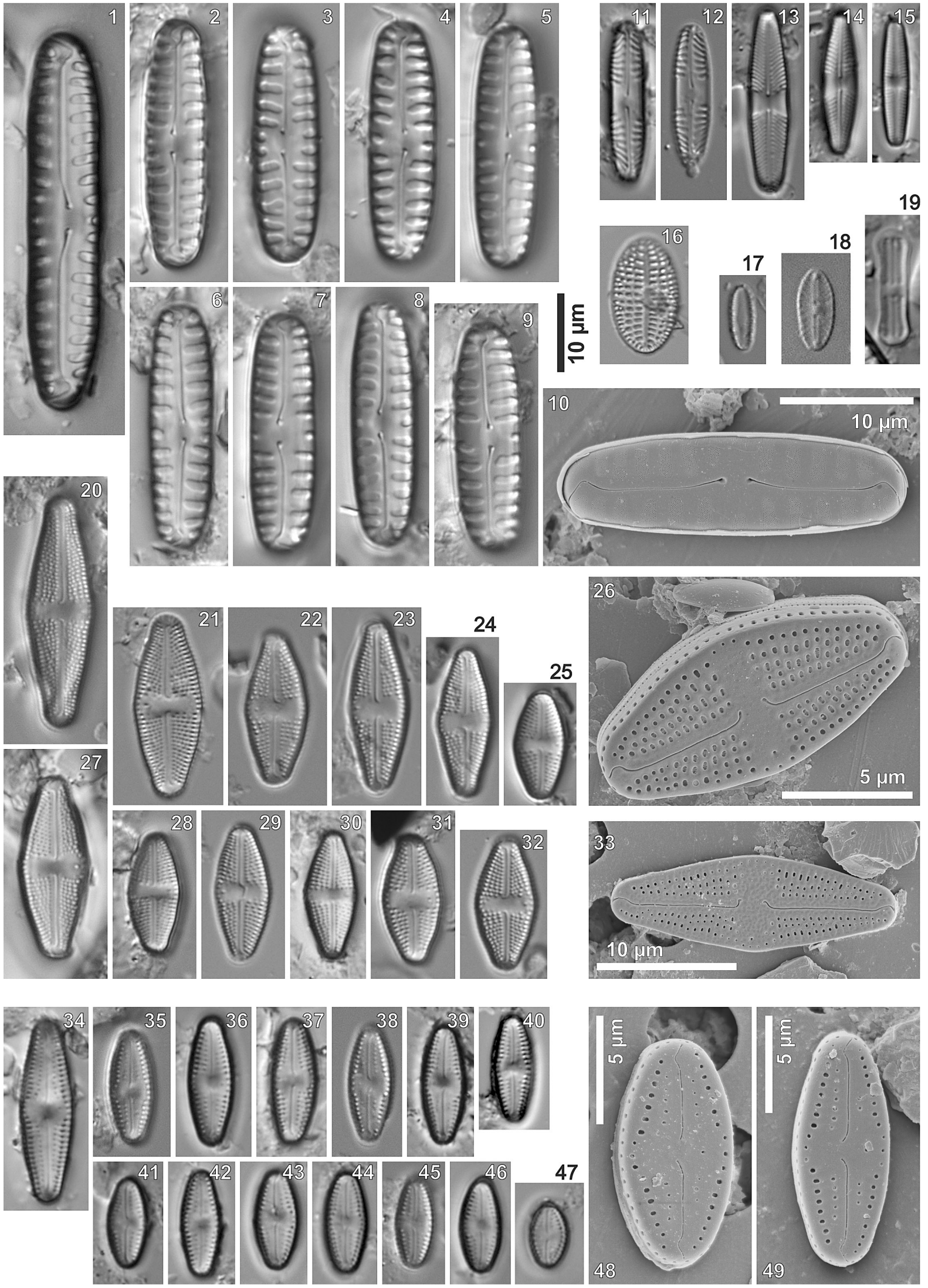

Fig. 1. Selected diatom taxa: 1-10 - Pinnularia borealis, 11-12 - P. obscura, 13 - Stauroneis borrichii, 14 - S. lundii, 15 - Sellaphora atomoides, 16 - Cocconeis pseudolineata, 17 - Humidophila gallica,

18 - Mayamaea atomus, 19 - Humidophila contenta, 20-33 - Luticola acidoclinata, 34-49- L. sparsipunctata 

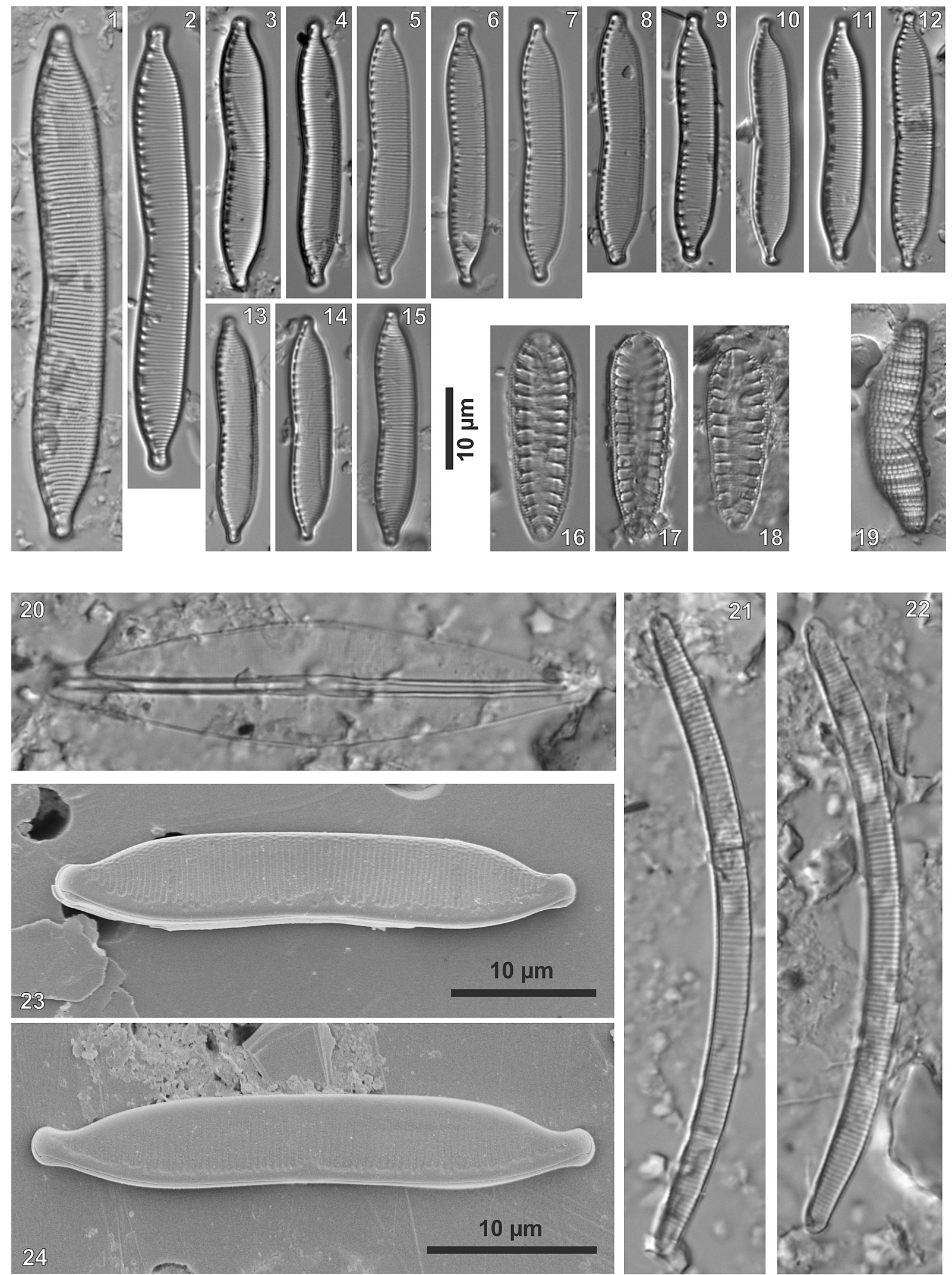

Fig. 2. Selected diatom taxa: 1 - Hantzschia subrupestris, $2-H$. calcifuga, 3-15 and 23-24 - H. amphioxys, 16-18 - Surirella minuta, 19 - Epithemia adnata, 20 - Frustulia saxonica, 21-22 - Eunotia bilunaris 
Table 3. The number of diatoms frustules with the number of taxa and dominants found at different heights above ground level in particular research seasons. for the dominants, the total number of frustules counted in the sample was given

\begin{tabular}{|l|c|c|c|c|c|c|c|}
\hline \multicolumn{1}{|c|}{ Date } & \multicolumn{2}{c|}{03.2016} & \multicolumn{2}{c|}{03.2017} & \multicolumn{2}{c|}{06.2017} & 08.2017 \\
\hline High above soil level & $20 \mathrm{~cm}$ & $150 \mathrm{~cm}$ & $20 \mathrm{~cm}$ & $150 \mathrm{~cm}$ & $20 \mathrm{~cm}$ & $150 \mathrm{~cm}$ & $20 \mathrm{~cm}$ \\
\hline $\begin{array}{l}\text { Number of all frustules counted in } \\
\text { sample }\end{array}$ & 224 & 22 & 292 & 31 & 247 & 21 & 293 \\
\hline Total number of taxa & 29 & 6 & 20 & 12 & 19 & 10 & 23 \\
\hline Number of dominant taxa in sample & 1 & 0 & 1 & 0 & 3 & 0 & 3 \\
\hline Hantzschia amphioxys & 43 & 9 & 144 & 13 & 54 & 3 & 103 \\
\hline Luticola acidoclinata & 97 & 0 & 22 & 0 & 79 & 10 & 70 \\
\hline Pinnularia borealis & 43 & 7 & 39 & 1 & 78 & 1 & 68 \\
\hline
\end{tabular}

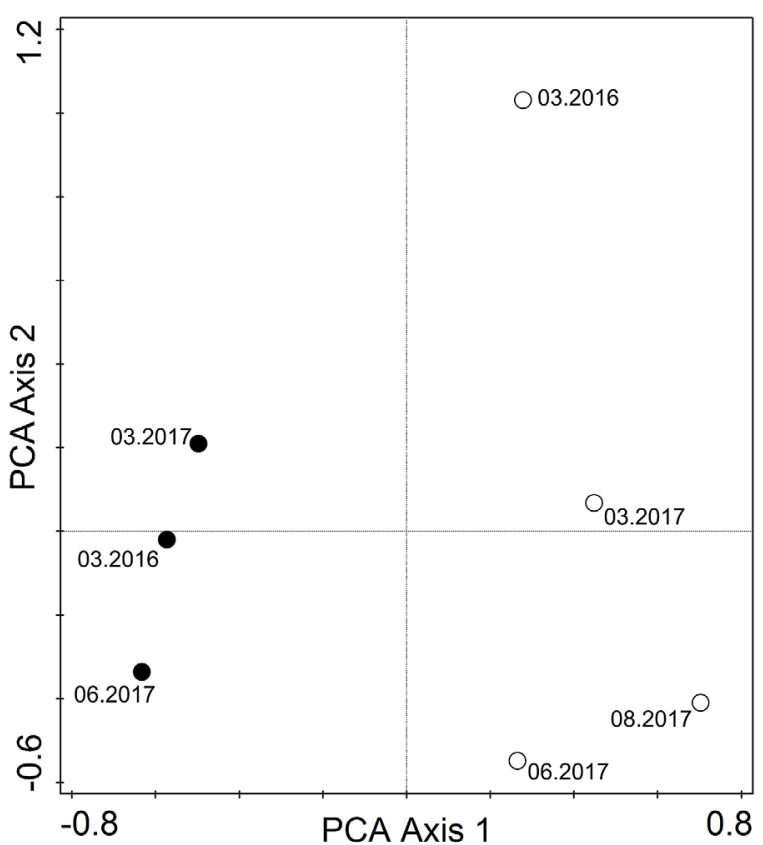

Fig 3. PCA ordination of sampling sites determined by relative community composition. Clusters represent sites of similarity based on height of sampling on three bark (black points $-150 \mathrm{~cm}$, white points $-20 \mathrm{~cm}$ )

from Poland: Hantzschia subrupestris, Luticola sparsipunctata and L. vanheurckii.

\section{DISCUSSION}

The values of chemical parameters measured in the filtrates of the white poplar bark showed large fluctuations throughout the year. The electrolytic conductivity, the ions (especially nutrients) and $\mathrm{pH}$ decreased significantly in summer in comparison to the early spring in 2016 and 2017. All chemical parameters had the lowest values in August. This is probably the result of nutrients leaching by rainwater (from retained dust and decay of the bark).
The bark of trees, due to its porosity, absorbs rainwater and in this way undergoes acidification. The degree of acidification depends on the bark structure, which is different depending on the tree species (Zimny 2006). The $\mathrm{pH}$ characterizing the bark of the Acer platanoides L., Fraxinus excelsior L. and Tilia cordata Mill. in clean areas is usually subneutral (4.9-7.5), while in the Betula pendula Roth, Picea abies (L.) H. Karst. and Pinus sylvestris L. is generally acidic (Wirth 1995). Štifterová and Neustupa (2015) measured the $\mathrm{pH}$ of the bark in $\mathrm{KCl}$ and obtained the highest values (about 5.5) for the maple (A. platanoides, A. pseudoplatanus L.), while Marmor and Randlane (2007) measured the bark $\mathrm{pH}$ of the Tilia cordata (also in KCL), which resulted in the $\mathrm{pH}$ range from 4.1 to 5.5 .

Epicolous bryophytes also have specific preferences related to the chemical properties of a bark (Bates 2009). Typical epiphytic species inhabit the bark of deciduous trees, while the acidic bark of conifers is inhabited only at the base by forest floor species (Rydin 2009).

Only two species of mosses were found during the study, which can be considered as epiphytic. Both have overgrown bark at a height of 150 $\mathrm{cm}$ above soil level. Platygyrium repens (Brid.) Schimp. is a moss occurring mainly on the bark of trees and especially on rotting wood, while Orthotrichum speciosum Nees. is a typical epiphytic species associated with the bark of deciduous trees (Dierßen 2001, Ellenberg, Leuschner 2010).

The moss-inhabiting diatom assemblages were characterized by a high proportion of aerophytic species, which are able to grow outside the typical aquatic habitats. Many species from the genera: Hantzschia, Luticola and Mayamaea, as well as species: Muelleria gibbula, Pinnularia borealis, P. obscura or Stauroneis thermicola are usually noted in soils and very often domi- 
nated the diatom flora (Stanek-Tarkowska, Noga 2012a,b, Levkov et al. 2013, Stanek-Tarkowska et al. 2013, 2015, 2016, Barragán et al. 2017).

Hantzschia amphioxys and Pinnularia borealis form the largest populations in terrestrial environments and have wide ecological preferences. They are typical aerophytic and soil species, which can also develop besides aquatic environment, i.e. on moist walls, in wet rock crevices and among mosses (Bąk et al. 2012, Hofmann et al. 2011, Lange-Bertalot et al. 2017). Pinnularia borealis var. borealis is a cosmopoli$\tan$ species that can be often widely distributed by winds (Krammer 2000). In the studied material, $H$. amphioxys formed the most numerous populations and dominated the assemblages at the base of the trunk in almost every season, while $P$. borealis dominated the diatom flora only in the summer. In Podkarpacie region both species were noted in many rivers and streams, but always as single specimens (Noga et al. 2014), while on soils they are numerous and often dominant species (Stanek-Tarkowska, Noga 2012a,b, Stanek-Tarkowska et al. 2013, 2015, 2016).

The third dominant species - Luticola acidoclinata occurs in oligotrophic waters with circumneutral to slightly acidic. Formerly, it was reported as Luticola mutica var. intermedia (Hustedt) Hustedt (Hofmann et al. 2011, Bąk et al. 2012, Lange-Bertalot et al. 2017). Levkov et al. (2013) frequently reported populations of $L$. acidoclinata from oligotrophic, slightly acidic waters (springs, small rivers and peat bogs) and subaerial habitats, usually as epiphytic on mosses. Luticola acidoclinata is noted in the Red list of Algae in Poland as a rare species (R category) (Siemińska et al. 2006). In the Podkarpacie region, the species is found always as single specimens in the upper sections of small rivers and streams (Noga et al. 2014). The conducted study showed that in the aerophytical environment (among the mosses growing on the tree bark), L. acidoclinata developed in large numbers and dominated the diatom assemblages in three seasons (it was the only one dominant in March 2016). This species is also often observed on soils in southern Poland, especially on meadows, pastures, fallow lands, etc., which are overgrown with varying degrees by mosses (Poradowska, personal communication). All the information mentioned above suggests that $L$. acidoclinata is a rare species only in waters, but has the optimum occurrence in aerophytical environments, especially among mosses.
The remaining species from the $\mathrm{R}$ (rare) category were noted individually. Both Achnanthes coarctata and Stauroneis thermicola are aerophytic species that do not form numerous populations in aquatic environments. They are found in periodically dry habitats, especially on wet rocks and mosses (Hofmann et al. 2011, Bąk et al. 2012, Lange-Bertalot et al. 2017). In the Podkarpacie region, both species were reported individually in different types of waters (Noga et al. 2014), while Stauroneis thermicola developed numerously also in soils, where it was often one of the main dominant species. Therefore, it was considered as the soil species (Stanek-Tarkowska et al. 2013).

In the studied material, three species that have not previously been reported from Poland, were found. Among them, only Luticola sparsipunctata occurred in all of the studied seasons, but not as the dominant species. The other two species Hantzschia subrupestris and Luticola vanheurckii were found as single specimens only in the spring seasons.

So far, Luticola sparsipunctata is known only from type locality in the Czech Republic and Austria (Levkov et al. 2013) and from caves in Hawaii (Miscoe et al. 2016). It was described as a new species in 2013 (Levkov et al. 2013), therefore its ecology is still poorly known.

Luticola vanheurckii is also known only from the type locality in Belgium (Levkov et al. 2013). It was firstly observed in Poland in a small puddle in the city of Stalowa Wola - a few kilometres from the presented site (Noga, Rybak - in press). In the mosses collected from white poplar, only one valve was found.

In the spring of 2016, few Hantzschia subrupestris frustules were noted both at the base of the trunk and at a height of $150 \mathrm{~cm}$. So far, $H$. subrupestris is known only from a few localities, mainly from Europe (Lange-Bertalot 1993, 1996, Lange-Bertalot et al. 2003, Denys, Oosterlynck 2015, Veen et al. 2015), less often from North America (Bahls 2009).

Epicolous mossy sites, as habitat diatoms, have so far been poorly studied. Both rare and well-known diatom species can develop in this habitat. Usually, this kind of habitat is dominated by the aerophytic diatoms, which are resistant to lack of water and changing nutrient levels. These species also often occur in soils and on wet rocks. For this reason, the studies on diatom assemblages from arboreal mosses can extend the knowledge about the ecology, distribution and adaptability of many diatom species. 


\section{Acknowledgement}

The author wish to thank Prof. Andrzej Massalski for language correction of the manuscript.

\section{REFERENCES}

1. Bahls L.L. 2009. A checklist of diatoms from inland waters of the Northwestern United States. Proceedings of the Academy of Natural Sciences of Philadelphia, 158(1), 1-35.

2. Barragán C., Wetzel C.E., Ector L. 2017. A standard method for the routine sampling of terrestrial diatom communities for soil quality assessment. J. Appl. Phycol., https://doi.org/10.1007/ s10811-017-1336-7.

3. Bates J.W. 2009. Mineral nutrition and substratum ecology. In: B. Goffinet B., A.J. Shaw (Eds). Bryophyte Biology 2nd edition, Cambridge University Press, Cambridge, pp. 299-357.

4. Bąk M., Witkowski A., Żelazna-Wieczorek J., Wojtal A.Z., Szczepocka E., Szulc A. \& Szulc B. 2012. The guide to identyfication diatoms in phytobenthos for the purpose of assessing the ecological status of surface waters in Poland. Biblioteka Monitoringu Środowiska. pp. 1-452. Warszawa, (in Polish).

5. Denys L., Oosterlynck P. 2015. Diatom assemblages of non-living substrates in petrifying Cratoneurion springs from lower Belgium. Fottea, 15(2), 123-138.

6. Dierßen K. 2001. Distribution, ecological amplitude and phytosociological characterization of European bryophytes. Bryophytorum Bibliotheca, 56, $1-289$.

7. Ellenberg H., Leuschner C. 2010. Vegetation Mitteleuropas mit den Alpen. Ulmer, Stuttgart, pp 1357.

8. Foerester J.W. 1971. The ecology of an elfin forest in Puerto Rico. 14. The algae of Pico del Oeste. Arnold Arboretum, 52, 86-109.

9. Geissler U., Kusber W-H., Jahn R. 2006. The diatom flora of Berlin (Germany): A spotlight on some documented taxa as a case study on historical biodiversity. In: A. Witkowski (Ed.) Eighteenth International Diatom Symposium 2004 Międzyzdroje, Poland, pp. 91-105, Biopress Limited, Bristol. 3.

10. Glime J. M. 2017. Chapter 1 - The Fauna: A Place to Call Home. Bryophyte Ecology Volume 2: Bryological Interaction, 1, 1-16.

11. Gremmen N., Van De Vijver B., Frenot Y., Lebouvier M. 2007. Distribution of moss-inhabiting diatoms along an altitudinal gradient at sub-Antarctic Îles Kerguelen. Antarctic Science, 19(1), 17-24.

12. Hickman M., Vitt D.H. 1973. The aerial epiphytic diatom flora of moss species from subantatctic
Campbell Island. Nova Hedwigia, 24, 443-458.

13. Hofmann G., Werum M., Lange-Bertalot H. 2011. Diatomeen im Süßwasser - Benthos von Mitteleuropa. Bestimmungsflora Kieselalgen für die ökologische Praxis. Über 700 der häugfisten Arten und ihre Ökologie. [In:] H. Lange-Bertalot, (Ed.): 908 pp. A.R.G. Gantner Verlag K.G., Ruggell.

14. Kawecka B., Eloranta P.V. 1994. Basics of the ecology of freshwater algae and terrestrial environments. PWN, Warszawa, 256 pp. (in Polish).

15. Kharkongor D., Ramanujam P. 2014. Diversity and species composition of subaerial algal communities on forested areas of Meghalaya, India. Hindawi Publishing Corporation International Journal of Biodiversity, Vol. 2014, Article ID 456202, 10 pages, http://dx.doi.org/10.1155/2014/456202.

16. Krammer K. 2000. The genus Pinnularia. [In:] H. Lange-Bertalot (Ed.): Diatoms of Europe. Vol. 1., 703 pp. A.R.G. Gantner Verlag K.G.

17. Krammer K., Lange-Bertalot H. 1986. Bacillariophyceae. 1. Naviculaceae. In: H. Ettl, J. Gerloff, H. Heyning, D. Mollenhauer (Eds): Süsswasserflora von Mitteleuropa 2(1), 876 pp. G. Fischer Verlag, Stuttgart - New York.

18. Krammer K., Lange-Bertalot H. 1988. Bacillariophyceae. 2. Bacillariaceae, Epithemiaceae, Surirellaceae. In: H. Ettl, J. Gerloff, H. Heyning, D. Mollenhauer (Eds): Süsswasserflora von Mitteleuropa 2(2), 596 pp. G. Fischer Verlag, Stuttgart - New York.

19. Krammer K., Lange-Bertalot H. 1991a. Bacillariophyceae. 3. Centrales, Fragilariaceae, Eunotiaceae. In: H. Ettl, J. Gerloff, H. Heyning, D. Mollenhauer (Eds): Süsswasserflora von Mitteleuropa 2(3), 576 pp. G. Fischer Verlag, Stuttgart - Jena.

20. Krammer K., Lange-Bertalot H. 1991b. Bacillariophyceae. 4. Achnanthaceae, Kritische Ergänzungen zu Navicula (Lineolate) und Gomphonema, Gesamtliteraturverzeichnis. In: Ettl, H., Gerloff, J., Heyning, H., Mollenhauer, D. (Eds): Süsswasserflora von Mitteleuropa 2(4), G. Fischer Verlag, Stuttgart - Jena, 437 pp.

21. Lakatos M., Lange-Bertalot H., Büdel B. 2004. Diatoms living inside the thallus of the green algal lichen Coenogonium linkii in neotropical lowland rain forests. Journal of Phycology, 40, 70-73.

22. Lange-Bertalot H. 1993. 85 neue Taxa und über 100 weitere neu definierte Taxa ergänzend zur Süsswasserflora von Mitteleuropa, Vol. 2/1-4. Bibliotheca Diatomologica, 27, 1-164.

23. Lange-Bertalot H. 1996. Rote liste der limnischen Kieselalgen (Bacillariophyceae) Deutschlands. Schriftenreihe für Vegetationskunde, 28, 633-677.

24. Lange-Bertalot H., Cavacini P., Tagliaventi N., Alfinito S. 2003. Diatoms of Sardinia: Rare and 76 new species in rock pools and other ephemeral wa- 
ters. Iconographia Diatomologica, 12, 1-438.

25. Lange-Bertalot H., Hofmann, Werum M., Cantonati M. 2017. Freshwater benthic diatoms of Central Europe: over 800 common species used in ecological assessments. English edition with updated taxonomy and added species. In: M. Cantonati et al. (Eds). Koeltz Botanical Books, Schmitten-Oberreifenberg, $942 \mathrm{pp}$.

26. Levkov Z., Metzeltin D., Pavlov A. 2013. Luticola and Luticolopsis. In: H. Lange-Bertalot, (Ed.), Diatoms of Europe. Vol. 7. Köningstein/Germany: Koeltz Scientific Books, 698 pp.

27. Lindo Z., Gonzales A. 2010. The Bryosphere: An Integral and Influential Component of the Earth's Biosphere. Ecosystems, 13, 612-627.

28. Marmor L., Randlane T. 2007. Effects of road traffic on bark $\mathrm{pH}$ and epiphytic lichens in Tallinn. Folia Cryptog. Estonica, Fasc., 43, 23-37.

29. Miscoe, L.H., Johansen, J.R., Kociolek, J.P., Lowe, R.L. 2016. The diatom flora and cyanobacteria from caves on Kauai, Hawaii. I. Investigation of the cave diatom flora of Kauai, Hawaii: an emphasis on taxonomy and distribution. Bibliotheca Phycologica, 123, 3-74.

30. Mrozińska T. 1990. Aerophitic algae from North Korea. Algological Studies, 58, 28-47.

31. Neustupa J. 2003. The genus Phycopeltis (Trentepohliales, Chlorophyta) from tropical Southeast Asia. Nova Hedwigia, 76, 487-505.

32. Neustupa J. 2005. Investigations on genus Phycopeltis (Trentepohliaceae, Chlorophyta) from SouthEast Asia, including the description of two new species. Cryptogamia Algologica, 26, 229-242.

33. Neustupa J., Škaloud P. 2008. Diversity of subaerial algae and cyanobacteria on tree bark in tropical mountain habits. Biologia, 63(6), 806-812.

34. Neustupa J., Škaloud P. 2010. Diversity of subaerial algae and cyanobacteria growing on bark and wood in the lowland tropical forests of Singapore. Plant Ecology and Evolution, 143(1), 51-62.

35. Noga T., Kochman N., Peszek Ł., Stanek-Tarkowska J., Pajączek A. 2014. Diatoms (Bacillariophyceae) in rivers and streams and on cultivated soils of the Podkarpacie Region in the years 2007-2011. Journal of Ecological Engineering, 15(1), 6-25.

36. Noga T., Stanek-Tarkowska J., Rybak M., KochmanKędziora N., Peszek Ł., Pajączek A. 2016. Diversity of diatoms in the natural, mid-forest Terebowiec stream - Bieszczady National Park. Journal of Ecological Engineering, 17(4), 232-247.

37. Nováková J., Poulíčková A. 2004. Moss diatom (Bacillariophyceae) flora of the Nature Reserve Adršpašsko-Teplické Rocks (Czech Republic). Czech Phycology, Olomouc, 4, 75-86.

38. Ochyra, R., Żarnowiec, J., Bednarek-Ochyra H.
2003. Census Catalogue of Polish mosses. Polish Academy of Sciences, Institute of Botany, Kraków, 372 pp.

39. Plášek V. 2013. Bryophytes in forests. Field guide for foresters and valuators. Centrum Informacyjne Lasów Państwowych, Warszawa, 130 pp. (in Polish).

40. Podbielkowski Z. 1996. Algae - Glony. WSiP, Warszawa, 215 pp. (in Polish).

41. Poulícková A., Hájková P., Krenková P., Hájek M. 2004. Distribution of diatoms and bryophytes on linear transects through spring fens. Nova Hedwigia, 78(3-4), 411-424.

42. Qin B., Zheng M., Chen X., Yang X. 2016. Diatom composition of epiphytic bryophytes on trees and its ecological distribution in Wuhan City. Chinese Journal of Ecology, 35(11), 2983-2990.

43. Round F.E. 1957. The diatom community of some Bryophyta growing on sandstone. Botanical Journal of the Linnean Society, 55(362), 657-661.

44. Rydin H. 2009. Population and community ecology of bryophytes In: B. Goffinet B., A.J. Shaw (Eds). Bryophyte Biology $2^{\text {nd }}$ edition, Cambridge University Press, Cambridge, p. 393-444.

45. Salleh A., Milow P. 1999. Notes on Trentepohlia dialepta (Nylander) Hariot (Trentepohliaceae, Chlorophyta) and sporangia of some other species of Trentepohlia Mart. from Malaysia. Micronesica, 31, 675-692.

46. Siemińska J., Bąk M., Dziedzic J., Gąbka M., Gregorowicz P., et al. 2006. Red list of the algae in Poland - Czerwona lista glonów w Polsce. In: Z. Mirek et al. (Eds) Red list of plants and fungi in Poland - Czerwona lista roślin i grzybów Polski. Polish Academy of Sciences, Kraków, 35-52.

47. Schmidt J., Kricke R., Feige G.B. 2001. Measurements of bark $\mathrm{pH}$ with a modifiedflathead electrode. Lichenologist, 33, 456-460.

48. Smith A.J.E. 2004. The Moss Flora of Britain and Ireland 2nd edition. Cambridge University Press, Cambridge, New York, Melbourne, Madrid, Cape Town, Singapore, São Paulo, pp. 1012.

49. Stanek-Tarkowska J., Noga T. 2012a. The diatoms communities developing on dust soils under sweet corn cultivation in Podkarpackie region. Fragmenta Floristica et Geobotanica Polonjca, 19(2), 525-536.

50. Stanek-Tarkowska J., Noga T. 2012b. Diversity of diatoms (Bacillariophyceae) in the soil under traditional tillage and reduced tillage. Inżynieria Ekologiczna, 30, 287-296.

51. Stanek-Tarkowska J, Noga T, Pajączek A, Peszek Ł. 2013. The occurrence of Sellaphora nana (Hust.) Lange-Bert. Cavacini, Tagliaventi and Alfinito, Stauroneis borrichii (J.B. Petersen) J.W.G. Lund, S. parathermicola Lange-Bert. and S. thermicola (J.B. Petersen) J.W.G. Lund on agricultural 
soils. Algological Studies, 142, 109-120.

52. Stanek-Tarkowska J., Noga T., Kochman-Kędziora N., Peszek Ł., Pajączek A., Kozak E. 2015. The diversity of diatom assemblages developed on fallow soil in Pogórska Wola (Southern Poland). Acta Agrobotanica, 68(1), 33-42.

53. Stanek-Tarkowska J., Noga T., Kochman-Kędziora N., Rybak M. 2016. Diatom assemblages growing on cropping soil in Pogórska Wola near Tarnów. Inżynieria Ekologiczna, 46, 128-134 (in Polish).

54. Štifterová A., Neustupa J. 2015. Community structure of corticolous microalgae within a single forest stand: evaluating the effects of bark surface $\mathrm{pH}$ and tree species. Fottea, 15(2), 113-122.

55. Ter Braak C.J.F., Šmilauer P. 2012. Canoco reference manual and user's guide. Software for ordination (version 5.0). Microcomputer Power, Ithaca, NY, USA. 496 pp.
56. Thompson R.H., Wujek D.H. 1997. Trentepohliales: Cepaleuros, Phycopeltis and Stomatochroon. Morphology, taxonomy and ecology. Enfield, Science Publishing.

57. Van de Vijver B., Beyens L. 1997. The epiphytic diatom flora of mosses from Strømnes Bay area, South Georgia. Polar Biology, 17(6), 492-501.

58. Veen A., Hof C.H.J., Kouwets F.A.C. \& Berkhout T. 2015. Taxa Watermanagement the Netherlands (TWN) [Rijkswaterstaat Waterdienst, Informatiehuis Water] http://ipt.nlbif.nl/ipt/ resource? $\mathrm{r}=$ checklist-twn.

59. Wirth V. 1995. Die Flechten Baden-Württembergs, Teil 1. Stuttgart, Verlag Eugen Ulmer, 527 pp.

60. Zimny H. 2006. Ecological evaluation of the state of the environment. Bioindication and biomonitoring. ARW A. Gregorczyk, Warszawa, 264 pp. (in Polish). 